\title{
A Mohácsi-sziget fehérnyár-ligetei (Senecioni sarracenici-Populetum albae Kevey in Borhidi et Kevey 1996)
}

\author{
KEVEY Balázs \\ Pécsi Tudományegyetem, Ökológiai Tanszék; \\ 7624 Pécs, Ifjúság u. 6.; keveyb@gamma.ttk.pte.hu \\ Elfogadva: 2017. március 11.
}

Kulcsszavak: Alföld, ligeterdő, nemzeti park, sokváltozós elemzések, szüntaxonómia.

\begin{abstract}
Összefoglalás: Jelen tanulmány a Magyarország déli részén levő Duna-ártér fehérnyár-ligeteinek (Senecioni sarracenici-Populetum albae) társulási viszonyait mutatja be 25 cönológiai felvétel alapján. Laza öntéshomok alapkőzeten és nyers öntéstalajon kialakult állományaik az alacsony ártér viszonylag magasabb szintjeit foglalják el. Faji összetételükkel és fejlett cserjeszintjükkel jól elkülöníthetők a mintegy 1-1,5 m-rel mélyebben fekvő, kötött és iszapos talajú, cserjeszint nélküli füzligetektől (Leucojo aestivi-Salicetum albae), valamint a magasabb ártéri szinten fejlődő tölgykőris-szil ligetektől (Scillo vindobonensis-Ulmetum). Aljnövényzetükben egyes - részben szubmontán jellegü - növények is megjelenhetnek, amelyek az Alföld egyéb tájain ritkák, vagy teljesen hiányoznak: Anemone ranunculoides, Carex brizoides, Carex remota, Carex strigosa, Carpesium abrotanoides, Fritillaria meleagris, Galanthus nivalis, Leucojum aestivum, Scilla vindobonensis, Veronica montana, Vitis sylvestris. Az asszociáció a szüntaxonómiai rendszer „Populenion nigro-albae Kevey 2008" alcsoportjába helyezhető.
\end{abstract}

\section{Bevezetés}

Mint ismeretes, a hazai puhafás ligeterdeinket sokáig füz-nyár ligeterdőként Salicetum albae-fragilis néven tartottuk nyilván (vö. Simon 1957; Soó 1958, 1964, 1973, 1980). Később bizonyítást nyert, hogy e puhafás ligeterdők Magyarországon három asszociációt foglalnak magukba (vö. KEveY 1993; Kevey in Borhidi és Kevey 1996; Kevey 2008). Ezek egyike a Szigetközből leírt fehérnyár-liget (Senecioni sarracenici-Populetum albae Kevey in Borhidi et Kevey 1996), amely később nemcsak a Duna-vidék egyéb tájain (Csepel-sziget: Kevey ined.; Sárköz Kevey ined.; Mohácsi-sziget: Kevey ined.), hanem a Dráva (vö. Kevey 2008; Kevey és Tóth 2006), a Mura (Kevey 2014), a Rába (Kevey ined.), a Bodrogköz (SzIrmai et al. 2008) és a Tisza mellől (KeVEy és BARNA 2014 ) is előkerült. Jelen tanulmányban a Mohácsi-sziget fehérnyár-ligeteit mutatom be 25 felvétel alapján. 
Kevey B.

\section{Anyag és módszer}

\section{A kutatási terület jellemzése}

A Mohácsi-szigeten a fehérnyár-ligetek a Nagy-Duna hullámterén találhatók. Botanikai értelemben ide kell sorolni a Duna jobb parti hullámterét is, ugyanis egy folyó jobb- és bal partjának vegetációja gyakorlatilag azonos. A folyami hordalékot elsősorban durva, másutt finom homok képezi, míg a mellékágak feltöltődése homokos iszappal történik. A vizsgált fehérnyár-ligetek (Senecioni sarracenici-Populetum albae) az alacsony ártér homokos és viszonylag magasabb szintjein találhatók, elkülönülve a mintegy 1-1,5 m-rel mélyebben fekvő és iszapos talajú szinteket borító fehérfüz-ligetektől (Leucojo aestivi-Salicetum albae) (vö. KEVEY 1993, 2008). Vizsgált állományaik 85-87 m tengerszint feletti magasság mellett fordulnak elő, laza szerkezetű, homokos, nyers öntéstalajokon.

\section{Alkalmazott módszerek}

A cönológiai felvételek a Zürich-Montpellier növénycönológiai iskola (BECKING 1957; BRAUN-BLANQUET 1964) hagyományos kvadrátmódszerével készültek. A felvételek táblázatos összeállítása, valamint a karakterfajok csoportrészesedésének és csoporttömegének kiszámítása az „NS” számítógépes programcsomaggal (KEVEY és HiRMANN 2002) történt. A felvételkészítés és a hagyományos statisztikai számítások - kissé módosított - módszerét korábban részletesen közöltem (KEVEY 2008). A Syn-Tax 2000 program (PoDANi 2001) segítségével bináris cluster-analízist (fúziós algoritmus: csoportátlag; hasonlósági index: Baroni-Urbani et Buser) és ordinációt végeztem (fúziós algoritmus: főkoordináta-analízis; hasonlósági index: Baroni-Urbani et Buser).

A fajok esetében KIRÁLY (2009), a társulásoknál pedig BORHIDI és KEVEY (1996), KEVEY (2008), ill. BoRHIDI et al. (2012) nómenklatúráját követem. A társulástani és a karakterfaj-statisztikai táblázatok felépítése az újabb eredményekkel (OBERDORFER 1992; MUCINA et al. 1993; BorHidi et al. 2012; KEVEY 2008) módosított Soó (1980) féle cönológiai rendszerre épül. A növények cönoszisztematikai besorolásánál is elsősorban Soó $(1964,1966,1968,1970$, 1973, 1980) Synopsis-ára támaszkodtam, de figyelembe vettem az újabb kutatási eredményeket is (vö. BORHIDI 1993, 1995; HORVÁTH et al. 1995; Kevey ined.).

\section{Eredmények}

Fiziognómia

A vizsgált fehérnyár-ligetek felső lombkoronaszintje az állomány korától függően 23-28 m magas és közepesen záródó (60-75\%). Állandó (K V) faja csak a 
Populus alba, s csak ez a fafaj tölt be állományalkotó (A-D: 3-4) szerepet. Mellette egyéb öshonos elegyfák is elöfordulnak: Fraxinus angustifolia, Populus nigra, Quercus robur, Salix alba, Ulmus laevis. Olykor megjelenik a fák lombkoronájában a Viscum album, és liánként elérheti e szintet a Vitis sylvestris és a Vitis riparia. Az alsó lombkoronaszint változóan fejlett. Magassága 15-20 m, borítása pedig 5-50\%. Főleg alászorult fák alkotják, közülük a Populus alba, az Ulmus laevis és az idegenhonos Fraxinus pennsylvanica érhet el nagy állandóságot (K IV). Nagyobb tömeget (A-D: 3) csak az idegenhonos Acer negundo képez. A cserjeszint erősen fejlett. Magassága 2-5 m, borítása legtöbbször $40-70 \%$, ritkábban kevesebb is lehet (20-30\%). Állandó (K IV-V) fajai a Cornus sanguinea, a Crataegus monogyna, valamint a tájidegen Acer negundo és a Fraxinus pennsylvanica. Nagyobb tömegben (A-D: 3-4) is ugyanez a négy faj fordul elö. Az alsó cserjeszint (újulat) változatosan fejlett, borítása 5-60\%. Állandó (K IV-V) fajai a következők: Cornus sanguinea, Populus alba, Quercus robur, Rubus caesius, Viburnum opulus, valamint a tájidegen Acer negundo és a Fraxinus pennsylvanica. Közülük nagyobb borítást (A-D: 3) csak a Rubus caesius ér el. A gyepszint többnyire fejlett (60-90\%), de akadnak gyérebb és közepes borítású (20-50\%) állományai is. Állandó (K IVV) fajai a következők: Carex remota, Carex strigosa, Circaea lutetiana, Galium aparine, Geum urbanum, Glechoma hederacea, Leucojum aestivum, Lysimachia nummularia, Poa trivialis, Ranunculus ficaria, Rumex sanguineus, Stellaria media, Symphytum officinale, Urtica dioica, Veronica hederifolia. Közülük fáciest (A-D: 3-4) csak a Glechoma hederacea, a Ranunculus ficaria és a Stellaria media képez (vö. E1-E2. táblázat, elektronikus mellékletben).

\section{Fajkombináció Állandósági osztályok eloszlása}

A 25 cönológiai felvétel alapján a társulásban 16 konstans ( $\mathrm{K} \mathrm{V}$ ) és 11 szubkonstans (K IV) faj szerepel az alábbiak szerint: - K V: Acer negundo, Carex remota, Circaea lutetiana, Cornus sanguinea, Fraxinus pennsylvanica, Galium aparine, Morus alba, Poa trivialis, Populus alba, Ranunculus ficaria, Rubus caesius, Rumex sanguineus, Stellaria media, Symphytum officinale, Ulmus laevis, Urtica dioica. - K IV: Carex strigosa, Crataegus monogyna, Fraxinus angustifolia, Geum urbanum, Glechoma hederacea, Leucojum aestivum, Lysimachia nummularia, Quercus robur, Ulmus minor, Veronica hederifolia, Viburnum opulus. Ezen kívül 21 akcesszórikus (K III), 21 szubakcesszórikus (K II) és 74 akcidens (K I) faj került elő. Az állandósági osztályok fajszáma tehát az akcidens (K I) fajoktól a szubkonstans (K IV) elemekig csökken, majd a konstans (K V) fajoknál ismét kissé magasabb (vö. E1-E2. táblázat (elektronikus mellékletben), 1. ábra). 


\section{Karakterfajok aránya}

Mint általában a puhafás ligeterdőkben, a Mohácsi-szigeten is a Salicetea purpureae (incl. Salicion albae) jellegü elemek fontos szerepet játszanak, amelyek 9,4\% csoportrészesedést és 16,9\% csoporttömeget mutatnak: - K IV: Leucojum aestivum. - K III: Salix alba. - K II: Crataegus nigra, Populus nigra. - K I: Humulus lupulus, Cucubalus baccifer. Arányuk hasonló, mint az Alföld egyéb tájegységein, de alacsonyabb, mint a Szigetközben (E3. táblázat, elektronikus mellékletben).

Jelentősek a keményfás ligeterdők elemei is (Alnion incanae incl. Alnenion glutinosae-incanae), amelyek csoportrészesedése $14,7 \%$, csoporttömege pedig 15,8\%: - K V: Carex remota, Populus alba, Rumex sanguineus, Ulmus laevis. - K IV: Carex strigosa, Fraxinus angustifolia, Viburnum opulus. - K III: Festuca gigantea. -

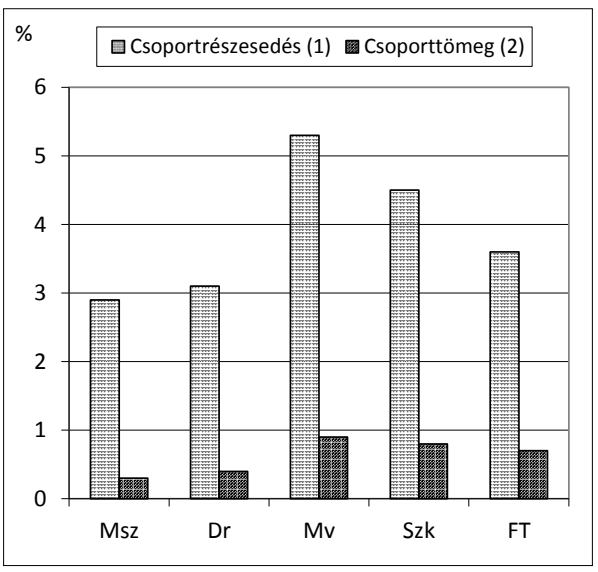

1. ábra. Phragmitetea s. l. fajok aránya fehérnyárligetekben (Senecioni sarracenici-Populetum albae). Msz: Mohácsi-sziget (Kevey ined.: 25 felv.); Dr: Dráva-ártér (Kevey és Tóth 2006: 20 felv.); Mv: Mura-vidék (Kevey 2014: 20 felv.); Szk: Szigetköz (Kevey 2008: 25 felv.); FT: FelsöTisza-vidék (Kevey és BARNA 2014: 25 felv.).

Fig. 1. Proportion of species characteristic of the class Phragmitetea s. l. in white poplar riparian forests (Senecioni sarracenici-Populetum albae). Legends: Msz: Mohácsi-sziget (Kevey ined.: 25 relevés); Dr: Dráva-ártér (Kevey and Tóth 2006: 20 relevés); Mv: Mura-vidék (Kevey 2014: 20 relevés); Szk: Szigetköz (Kevey 2008: 25 relevés); FT: Felső-Tisza-vidék (Kevey and BARNA 2014: 25 relevés); (1) Relative frequency;

(2) Relative frequency weighted with cover.

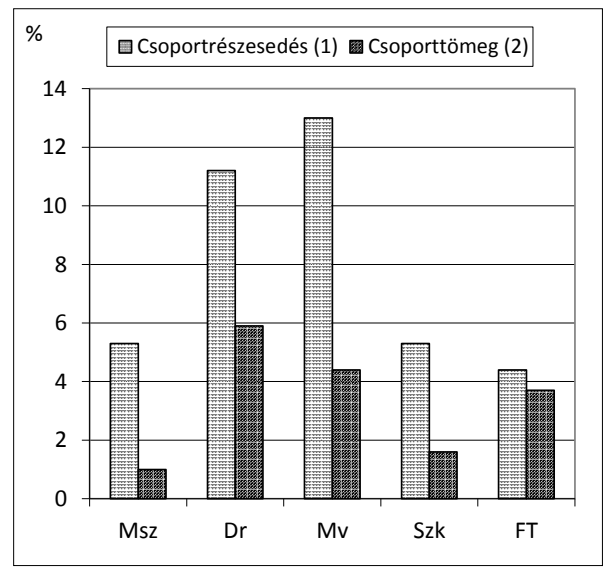

2. ábra. Fagetalia fajok aránya fehérnyárligetekben (Senecioni sarracenici-Populetum albae). Rövidítések mint az 1. ábrán.

Fig. 2. Proportion of species characteristic of the order Fagetalia in white poplar riparian forests (Senecioni sarracenici-Populetum albae). Legends as in Figure 1. 


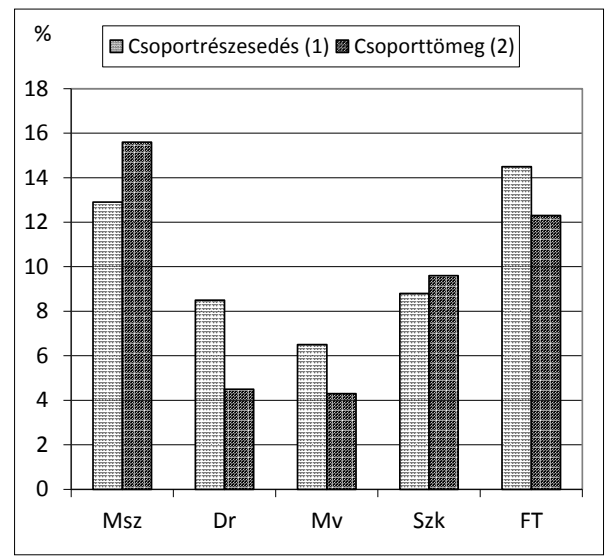

3. ábra. Adventív elemek aránya fehérnyárligetekben (Senecioni sarracenici-Populetum albae). Rövidítések mint az 1. ábrán.

Fig. 3. Proportion of introduced aliens in white poplar riparian forests (Senecioni sarracenici-Populetum albae). Legends as in Figure 1.

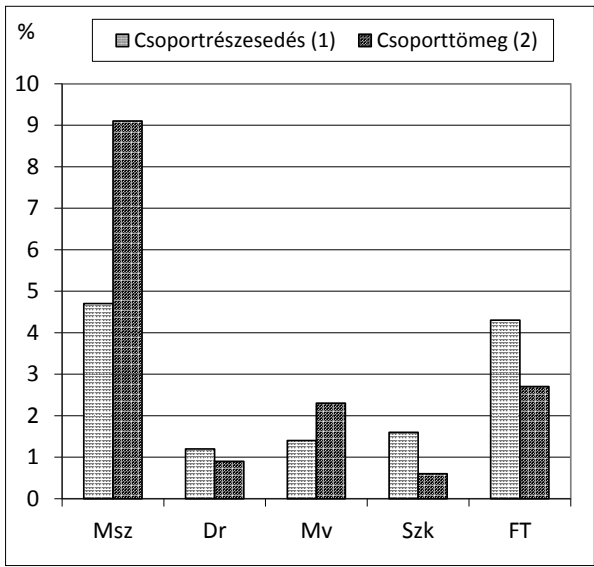

5. ábra. Meghonosodott idegen fajok (I) aránya fehérnyár-ligetekben (Senecioni sarracenici-Populetum albae). Rövidítések mint az 1 . ábrán. Fig. 5. Proportion of introduced species (I) in white poplar riparian forests (Senecioni sarracenici-Populetum albae). Legends as in Figure 1.

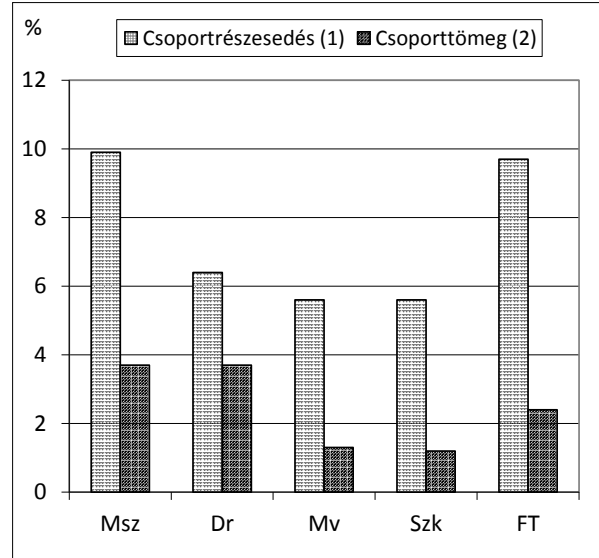

4. ábra. Természetes gyomok (W) aránya fehérnyár-ligetekben (Senecioni sarracenici-Populetum albae). Rövidítések mint az 1. ábrán.

Fig. 4. Proportion of weeds (W) in white poplar riparian forests (Senecioni sarracenici-Populetum albae). Legends as in Figure 1.

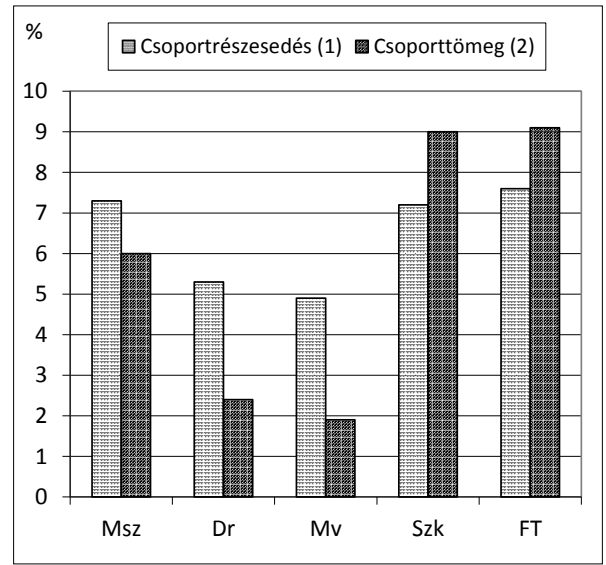

6. ábra. Agresszív tájidegen inváziós elemek (AC) aránya fehérnyár-ligetekben (Senecioni sarracenici-Populetum albae). Rövidítések mint az 1. ábrán.

Fig. 6. Proportion of invasive aliens (AC) in white poplar riparian forests (Senecioni sarracenici-Populetum albae). Legends as in Figure 1. 
Kevey B.

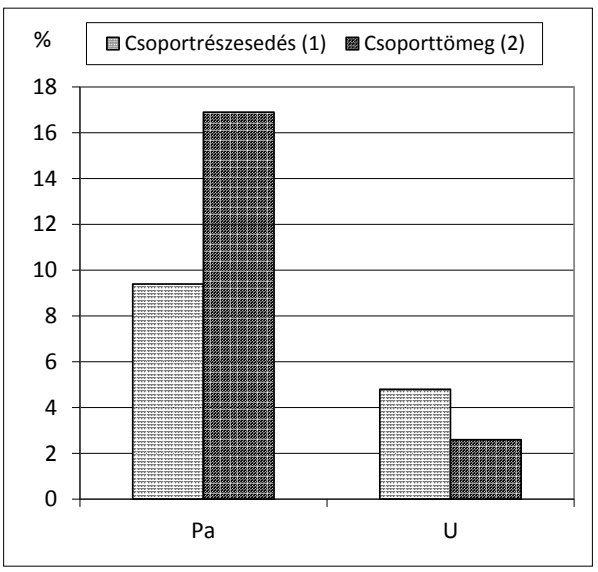

7. ábra. Salicetea purpureae s. l. fajok aránya a Mohácsi-sziget ligeterdeiben. Pa: Senecioni sarracenici-Populetum albae (Kevey ined.: 25 felv.); $\mathrm{U}$ : Scillo vindobonensis-Ulmetum (Kevey ined.: 25 felv.).

Fig. 7. Proportion of characteristic species of the class Salicetea purpureae s. 1. in the riparian forests on the Mohácsi-sziget. Pa: Senecioni sarracenici-Populetum albae (Kevey ined.: 25 relevés); U: Scillo vindobonensis-Ulmetum (Kevey ined.: 25 relevés); (1) Relative frequency; (2) Relative frequency weighted with cover.

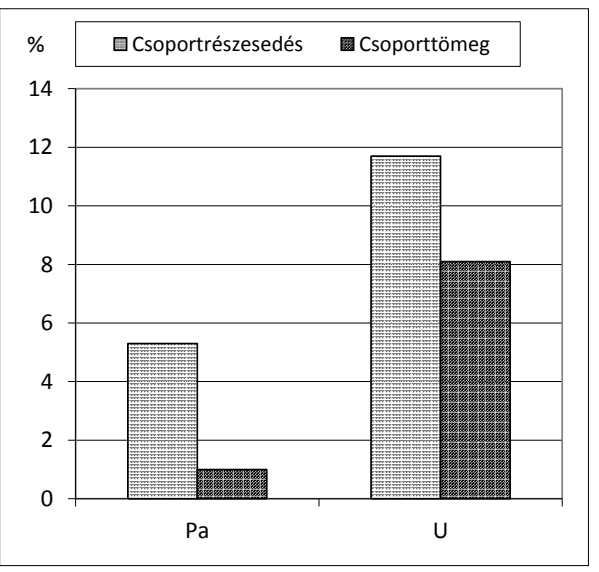

8. ábra. Fagetalia fajok aránya a Mohácsi-sziget ligeterdeiben. Rövidítések mint a 7. ábrán.

Fig. 8. Proportion of species characteristic of the order Fagetalia in the riparian forests on the Mohácsi-sziget. Legends as in Figure 7.

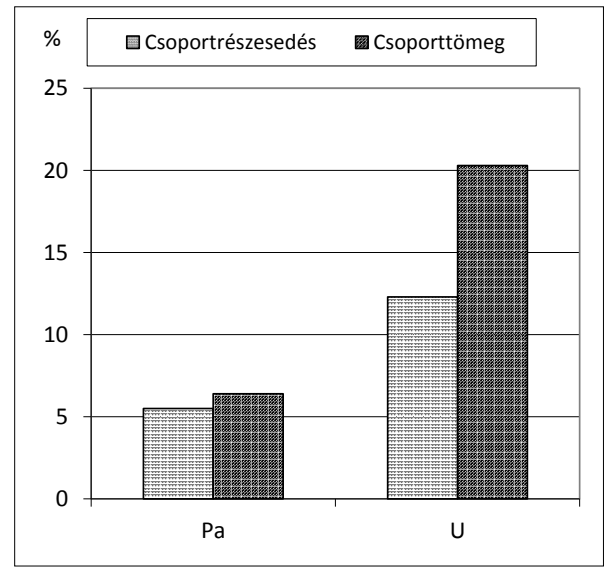

9. ábra. Quercetea pubescentis-petraeae fajok aránya a Mohácsi-sziget ligeterdeiben. Rövidítések mint a 7. ábrán.

Fig. 9. Proportion of characteristic species of the class Quercetea pubescentis-petraeae in the riparian forests on the Mohácsi-sziget. Legends as in Figure 7.

K II: Dipsacus pilosus. - K I: Carex brizoides, Frangula alnus, Impatiens noli-tangere, Malus sylvestris, Viola elatior, Vitis sylvestris. Arányuk hasonló, mint az Alföld egyéb tájain (E3. táblázat). 
Nem túlságosan gyakoriak, de - 5,3\% csoportrészesedéssel és 1,0\% csoporttömeggel -megjelennek a mezofil lomberdei (Fagetalia) elemek is: K V: Circaea lutetiana. - K III: Galeopsis speciosa, Carex sylvatica, Scilla vindobonensis. - K II: Hedera helix, Moehringia trinervia. - K I: Anemone ranunculoides, Galanthus nivalis, Veronica montana, Viola reichenbachiana. Arányuk hasonló, mint a Szigetközben és a Felső-Tisza-vidéken, de jóval alacsonyabb, mint a Dráva és a Mura árterén (E3. táblázat, 2. ábra).

A mocsári növények (Phragmitetea incl. Magnocaricion) nem oly gyakoriak, mint a füzligetekben (Leucojo aestivi-Salicetum albae), csoportrészesedésük 2,9\%, csoporttömegük pedig mindössze 0,3\%: - K II: Iris pseudacorus, Solanum dulcamara. - K I: Carex riparia, Eupatorium cannabinum, Euphorbia palustris, Galium palustre, Lycopus europaeus, Phalaris arundinacea, Phragmites australis, Poa palustris, Stachys palustris. Arányuk hasonló, mint a Dráva árterén, de lényegesen alacsonyabb, mint a Mura árterén és a Szigetközben (E3. táblázat, 1. ábra).

A ruderáliák közül ki kell emelni a Galio-Urticetea (incl. Galio-Alliarion et Calystegion sepium) elemeket, amelyek 7,0\% csoportrészesedést és 1,7\% csoporttömeget mutatnak: K III: Alliaria petiolata, Carpesium abrotanoides, Chaerophyllum temulum, Parietaria officinalis. - K II: Myosoton aquaticum, Aristolochia clematitis. - K I: Aethusa cynapium, Barbarea stricta, Calystegia sepium, Cuscuta europaea, Rumex obtusifolius (E3. táblázat).

Végül az adventív (Adventiva) elemek 12,9\% csoportrészesedést és 15,6\% csoporttömeget érnek el. E téren arányuk hasonlóan magas, mint a Felső-Tiszavidéken, messze megelőzve a Dráva, a Mura és a Szigetköz fehérnyár-ligeteit (E3. táblázat, 3. ábra).

A Mohácsi-szigetről a fehérnyár-ligetek mellett a tölgy-kőris-szil ligetekből is készítettem cönológiai felvételek (Kevey ined.). A két asszociáció karakterfajainak összehasonlítása szerint a Salicetea purpureae s.l. (7. ábra) elemek a fehérnyár-ligetekben, a Fagetalia (8. ábra) és Quercetea pubescentis-petraeae (9. ábra) fajok pedig a tölgy-kőris-szil ligetekben mutatnak lényegesen nagyobb arányt (E4. táblázat, elektronikus mellékletben).

\section{Szociális magatartási típusok aránya}

A szociális magatartási típusok (BORHIDi 1993, 1995) közül a specialisták $(S)$, a kompetítorok (C) és a generalisták (G) a Mohácsi-szigeten viszonylag hasonló arányt mutatnak, mint az Alföld egyéb tájain (E5. táblázat, elektronikus mellékletben). Ezzel szemben a természetes gyomok (W) és a meghonosodott idegen fajok (I) a Mohácsi-szigeten mutatják a legmagasabb értéket (4-5. ábra), de az agresszív tájidegen inváziós elemek aránya (6. ábra) is magas. 
Kevey B.
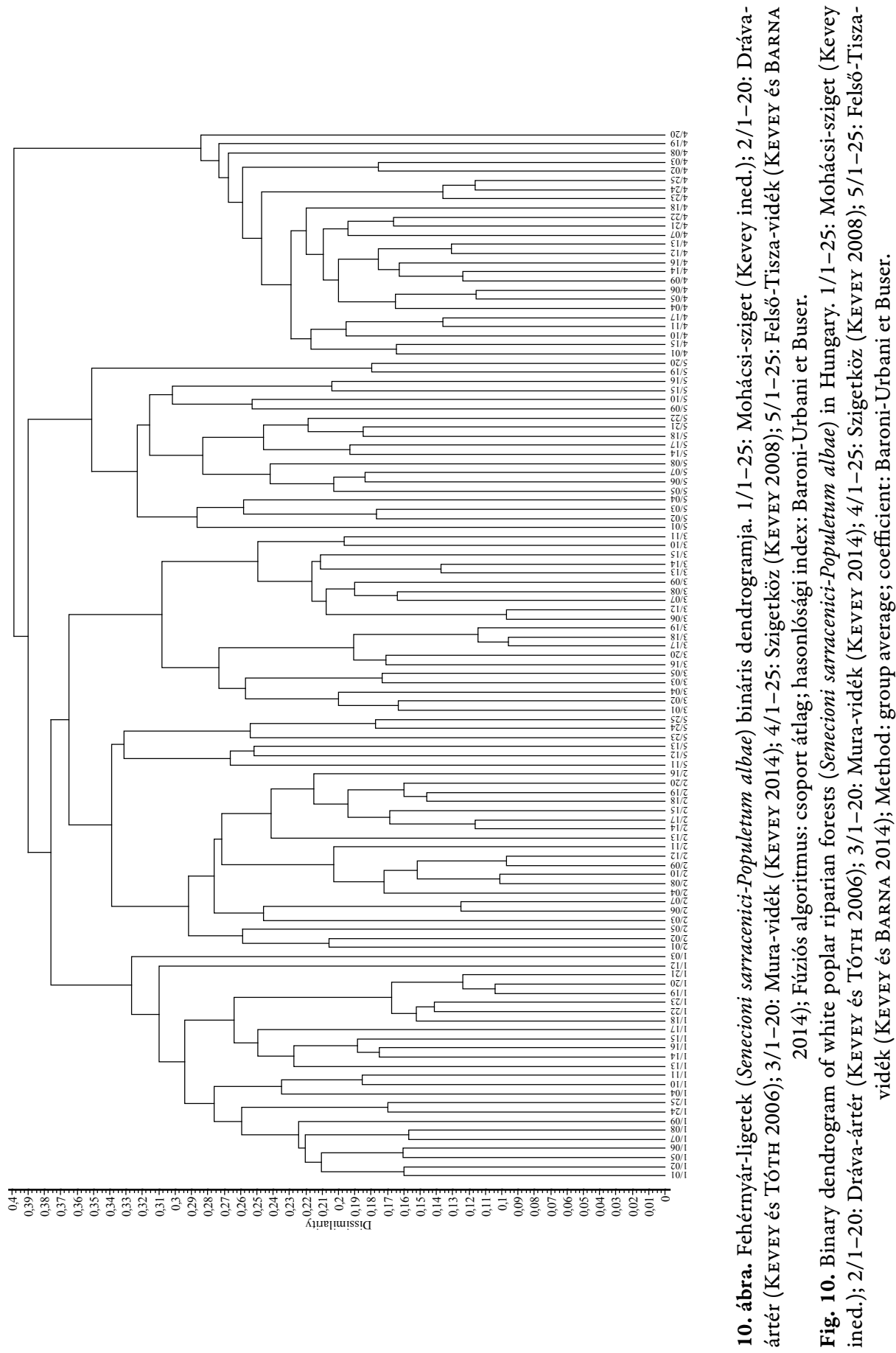


\section{Sokváltozós statisztikai elemzések eredményei}

Fenti hagyományos statisztikai számítások mellett néhány sokváltozós elemzést is végeztem. Ezek eredménye szerint az egymással összehasonlított fehérnyár-ligetek (Senecioni sarracenici-Populetum albae) között viszonylag nagymértékủ hasonlóság látható. A dendrogramon (10. ábra) és az ordinációs diagramon (11. ábra) földrajzi tájegységenkénti csoportosulások figyelhetők meg, de a szigetközi felvételek kissé jobban elkülönülnek a többitől. A Mohácsi-sziget fehérnyár-ligeteinek (Senecioni sarracenici-Populetum albae) és tölgy-kőris-szil ligeteinek (Scillo vindobonensis-Ulmetum) összehasonlításakor a két asszociáció felvételei elkülönülve két csoportba rendeződtek (12. és 13. ábra).

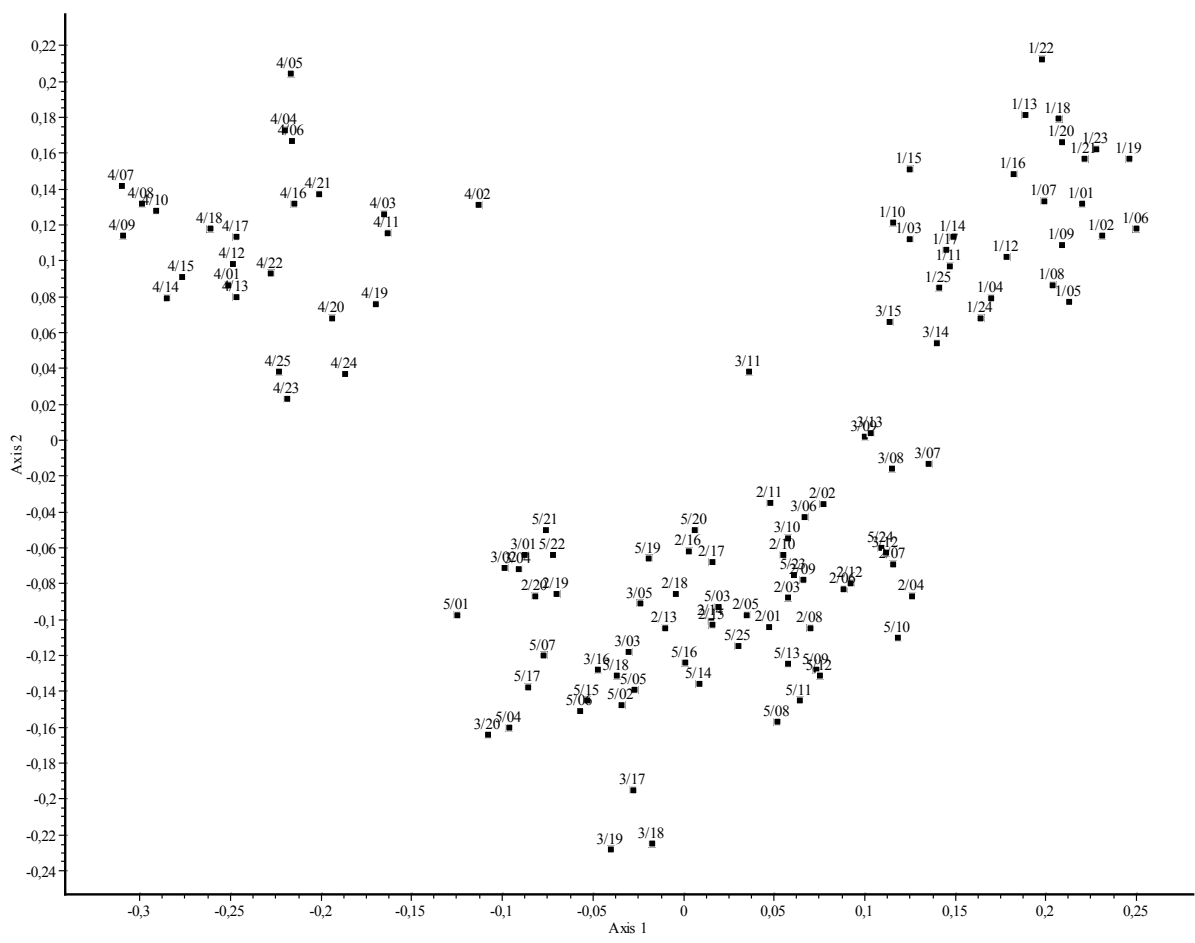

11. ábra. Fehérnyár-ligetek (Senecioni sarracenici-Populetum albae) bináris ordinációs diagramja. Algoritmus: főkoordináta analízis, hasonlósági index: Baroni-Urbani et Buser. Felvételek számozása a 10. ábra szerint.

Fig. 11. Binary ordination diagram of white poplar riparian forests (Senecioni sarracenici-Populetum albae) in Hungary. Method: principal coordinates analysis; Coefficient: Baroni-Urbani et Buser. Relevés as in Figure 10. 
Kevey B.

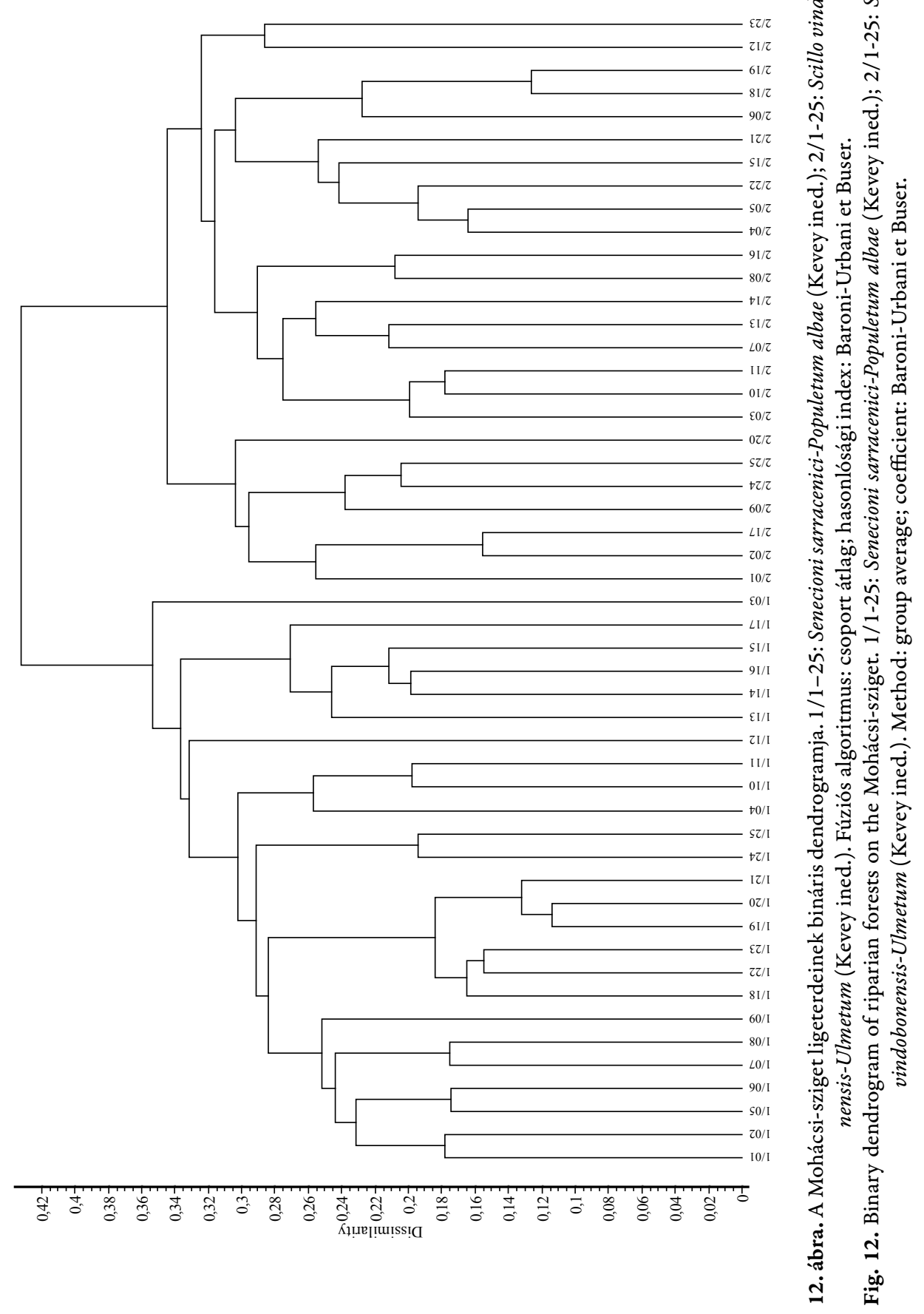




\section{Megvitatás}

Kutatásaim szerint a fehérnyár-ligetek (Senecioni sarracenici-Populetum albae) az Alföld különböző tájegységein (KeVEY 1993, 2008; KeVEY és BARNA 2014; Kevey et Huszár 1999; Kevey és Tóth 2006; Tóth 1958) elkülöníthetők a mélyebb ártéri szintek füzligeteitől (Leucojo aestivi-Salicetum albae), valamint a magasabban fekvő tölgy-kőris-szil ligetektől (Scillo vindobonensisUlmetum). Ezt az elkülönítést azonban több tényező is megnehezíti. Egyrészt a három asszociáció között vannak átmeneti jellegủ állományok is. Másrészt az ártereken tért hódító nemesnyár (Populus $\times$ euramericana agg.) ültetvények, valamint a spontán terjeszkedő tájidegen Acer negundo és Fraxinus pennsylvanica miatt a természetszerủ puhafás ligeterdők kisebb állományokká zsugorodtak. Ilyen körülmények mellett ma már nagyon nehéz természetszerű - cönológiai felvételre alkalmas - fehérnyár-ligeteket találni. Fenti zavartság ellenére az állandósági osztályok eloszlása szerint az akcidens (K I) fajok mellett a konstans (K V)

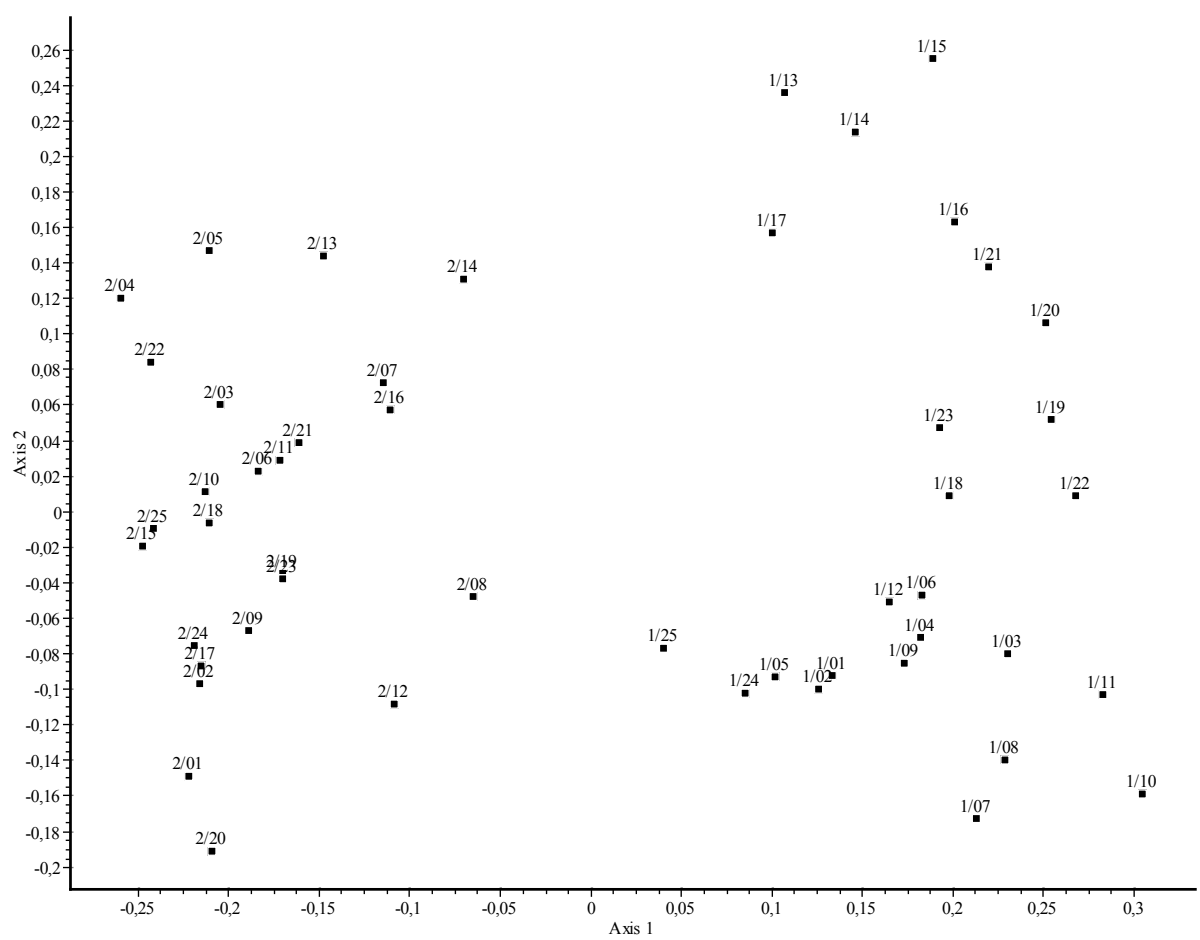

13. ábra. A Mohácsi-sziget ligeterdeinek bináris ordinációs diagramja. Algoritmus: főkoordináta analízis; hasonlósági index: Baroni-Urbani et Buser. Felvételek számozása a 12. ábra szerint.

Fig. 13. Binary ordination diagram of riparian forests on the Mohácsi-sziget. Algorithm: principal coordinates analysis; coefficient: Baroni-Urbani et Buser. Relevés as in Figure 12. 
elemeknél jelentkezik egy második maximum (E1. táblázat), s mindez arra utal, hogy a vizsgált állományok még mindig természet közeli állapotúak.

Ha összehasonlítjuk a Mohácsi-sziget, a Dráva-ártér, a Mura-vidék, a Szigetköz és a Felső-Tisza-vidék fehérnyár-ligeteit, azt tapasztaljuk, hogy a karakterfajok aránya sok esetben hasonló (E3. táblázat). Kisebb-nagyobb különbségek ugyan adódnak, de ezek nagyrészt a földrajzi távolsággal, a lokális vízrendezési viszonyokkal és az eltérő tájhasználattal lehetnek összefüggésben. Feltűnő, hogy a Fagetalia elemek a Mohácsi-sziget, a Szigetköz és a Felső-Tisza-vidék fehérnyár-ligeteiben jóval ritkábbak, mint a Dráva és a Mura árterén (2. ábra). Ennek oka nagyrészt az árhullámokkal hozható összefüggésbe, amelyek a Mohácsi-sziget, a Szigetköz és a Felső-Tisza-vidéken jóval gyakrabban jelentkeznek, mint a Dráva és a Mura mellett.

A sokváltozós elemzések (10-11. ábra) szerint az öt különböző ártéren vizsgált fehérnyár-ligetek között elég nagy a hasonlóság, bár tájegységenkénti kisebb csoportosulások figyelhetők meg. A dendrogramon érdekes módon a FelsőTisza-vidék felvételi anyagából hat felvétel a Dráva ártér felvételeihez kapcsolódott, amely némi bizonyítékul szolgál arra, hogy a hazai fehérnyár-ligetek egy társuláshoz tartoznak. Csupán a szigetközi felvételek mutatnak kissé nagyobb elkülönülést. E kisebb különbségek azonban nem indokolják a hazai fehérnyárligetek kisebb asszociációkra történő felbontását. Mind a hagyományos statisztikai (E3. táblázat, 1-2. ábra), mind pedig a sokváltozós analízisek (10-11. ábra) eredményei azt bizonyítják, hogy a Mohácsi-sziget fehérnyár-ligete - a termőhelyi viszonyok, a fiziognómia és a fajkombináció alapján - nagyon hasonlít a Szigetközből leírt Senecioni sarracenici-Populetum albae nevű asszociációhoz, ezért utóbbival azonosítható. A névadó Senecio sarracenicus ugyan e tájon nem került elö, ezért a társulás tudományos neve jelen esetben szimbolikusnak tekinthetö. Helye a növénytársulások rendszerében az alábbi módon vázolható:

\author{
Divízió: Querco-Fagea Jakucs 1967 \\ Osztály: Salicetea purpureae Moor 1958 \\ Rend: Salicetalia purpureae Moor 1958 \\ Csoport: Salicion albae Soó $1930 \mathrm{em}$. Th. Müller et Görs 1958 \\ Alcsoport: Populenion nigro-albae Kevey 2008 \\ Társulás:Senecionisarracenici-Populetum albae Kevey in Borhidi \\ et Kevey 1996
}

A Mohácsi-sziget fehérnyár-ligeteinek (Senecioni sarracenici-Populetum albae) és tölgy-kőris-szil ligeteinek (Scillo vindobonensis-Ulmetum) összehasonlító elemzésével (7-9. és 12-13. ábra) újabb bizonyítást nyert az, hogy a fehérnyár-ligetek (Senecioni sarracenici-Populetum albae) nem tekinthetők a tölgy-kőris-szil ligetek (Scillo vindobonensis-Ulmetum) fehérnyáras konszociációinak, hanem önálló asszociációt képeznek (vö. KeVEY 1993, 2008, 2016; KEVEY et BARNA 2014). 
Természetvédelmi vonatkozások

A vizsgált fehérnyár-ligetek mindegyike a Duna-Dráva Nemzeti Park területén van, ennek ellenére védelmük nincs kellőképp megoldva. A nemesnyár (Populus $\times$ euramericana) kultúrák térhódítása következtében a fehérnyár-ligetek egyre kisebb foltokká zsugorodtak, amelyhez az idegenhonos Acer negundo és Fraxinus pennsylvanica spontán terjeszkedése is hozzájárul. Helyzetüket tovább súlyosbítja a 35-40 éves puhafás ligeterdők tarra vágása. Megfigyelések szerint az így letermelt erdőrészek igen nehezen regenerálódnak, inkább degradálódnak, út nyílik a tájidegen (adventív) fajok özönszerủ terjeszkedése előtt. Ilyen növények a következők: K V: Acer negundo, Aster $\times$ salignus, Fraxinus pennsylvanica, Morus alba. - K III: Juglans regia, Oxalis fontana. - K II: Populus $\times$ euramericana, Robinia pseudo-acacia, Stenactis annua, Vitis vulpina. - K I: Ambrosia artemisiifolia, Amorpha fruticosa, Celtis occidentalis, Echinocystis lobata, Gleditsia triacanthos, Impatiens parviflora, Parthenocissus inserta, Solidago gigantea, Xanthium italicum (E1. táblázat). A Mohácsi-sziget fehérnyár-ligeteiben e növények 12,9\% csoportrészesedéssel és $15,6 \%$ csoporttömeggel fordulnak elő. $\mathrm{Ez}$ az arány jóval magasabb, mint a Dráva és a Mura árterén, valamint a Szigetközben (vö. E3. táblázat). A társulás viszonylagos degradált állapotára utal az is, hogy a természetes gyomok (W) és a meghonosodott idegen fajok (I) aránya a Mohácsi-sziget fehérnyár-ligeteiben a legnagyobb (4-5. ábra).

Fenti leromlás ellenére a 25 felvételből nyolc értékes védett növényfaj került elö: K IV: Carex strigosa, Leucojum aestivum. - K III: Carpesium abrotanoides, Scilla vindobonensis. - K II: Crataegus nigra. - K I: Fritillaria meleagris, Galanthus nivalis, Vitis sylvestris. Dendrológiai értéket képviselnek egyes hatalmas termetü fák (Populus alba, Quercus robur, Ulmus laevis), valamint egyes fává nőtt cserjék (Cornus sanguinea, Crataegus monogyna, Crataegus nigra). E fehérnyár-ligetek megőrzése és termőhelyük rekonstrukciója természetvédelmünk egyik fontos feladat lehetne.

\section{Köszönetnyilvánítás}

Köszönetem illeti Deme Tamás és Egerszegi Attila természetvédelmi őröket, akik kitűnő terepismeretükkel és hasznos információikkal segítették munkámat.

\section{Rövidítések}

A1: felső lombkoronaszint; A2: alsó lombkoronaszint; AF: Aremonio-Fagion; Ai: Alnion incanae; Alo: Alopecurion pratensis; AQ: Aceri tatarici-Quercion; Ar: Artemisietea; ArA: Artemisio-Agropyrion intermedii; Ara: Arrhenatheretea; Ate: Alnetea glutinosae; B1: cserjeszint; B2: újulat; Bec: Beckmannion eruciformis; Bia: Bidentetea; Bin: Bidention tripartiti; C: gyepszint; Cal: Calystegion sepium; Cgr: Caricenion graci- 
lis; Che: Chenopodietea; ChS: Chenopodio-Scleranthea; Cp: Carpinenion betuli; CyF: Cynodonto-Festucenion; Des: Deschampsion caespitosae; Epa: Epilobietea angustifolii; Epn: Epilobion angustifolii; FBt: Festuco-Brometea; FiC: Filipendulo-Cirsion oleracei; FPe: Festuco-Puccinellietea; FPi: Festuco-Puccinellietalia; GA: Galio-Alliarion; incl.: inclusive (beleértve); ined.: ineditum (kiadatlan közlés); Mag: Magnocaricetalia; Moa: Molinietalia coeruleae; MoA: Molinio-Arrhenatherea; MoJ: Molinio-Juncetea; Nc: Nanocyperion flavescentis; Pla: Plantaginetea; Pna: Populenion nigro-albae; PQ: PinoQuercetalia; Prf: Prunion fruticosae; Pru: Prunetalia spinosae; Pte: Phragmitetea; QFt: Querco-Fagetea; Qpp: Quercetea pubescentis-petraeae; Qr: Quercetalia roboris; S: summa (összeg); Sal: Salicion albae; SCn: Scheuchzerio-Caricetea nigrae; Sea: Secalietea; s. 1.: sensu lato (tágabb értelemben); Spu: Salicetea purpureae; TA: Tilio platyphyllaeAcerenion pseudoplatani; Ulm: Ulmenion; US: Urtico-Sambucetea.

\section{Irodalomjegyzék}

Becking R. W. 1957: The Zürich-Montpellier School of phytosociology. Botanical Review 23: 411-488. http://doi.org/10.1007/bf02872328

BoRHIDi A. 1993: A magyar flóra szociális magatartás típusai, természetességi és relatív ökológiai értékszámai. Janus Pannonius Tudományegyetem, Pécs, 95 pp.

BORHIDI A. 1995: Social behaviour types, the naturalness and relative ecological indicator values of the higher plants in the hungarian flora. Acta Botanica Academiae Scientiarum Hungaricae 39: 97-181.

BorHidi A., KEVEY B. 1996: An annotated checklist of the hungarian plant communities II. - In: BorHIDi A. (szerk.) Critical revision of the hungarian plant communities. Janus Pannonius University, Pécs, pp. 95-138.

Borhidi A., Kevey B., Lendvai G. 2012: Plant communities of Hungary. Akadémiai Kiadó, Budapest, $544 \mathrm{pp}$.

Braun-Blaneuet, J. 1964: Pflanzensoziologie (ed. 3.). Springer Verlag, Wien-New York, 865 pp.

Horváth F., Dobolyi Z. K., Morschhauser T., Lökös L., Karas L., Szerdahelyi T. 1995: Flóra adatbázis 1.2. Vácrátót, $267 \mathrm{pp}$.

JAKUCS P. 1967: Gedanken zur höheren Systematik der europäischen Laubwälder. Contribuții Botanici Cluj 1967: 159-166.

KEVEY B. 1993: A Szigetköz ligeterdeinek összehasonlító-cönológiai vizsgálata. Kandidátusi értekezés (kézirat). Janus Pannonius Tudományegyetem, Növénytani Tanszék, Pécs, 108 pp. + 32 fig. $+70 \mathrm{tab}$.

KeVey B. 2008: Magyarország erdőtársulásai (Forest associations of Hungary). Tilia 14: 1-488. + CD-adatbázis (230 táblázat +244 ábra).

Kevey B. 2014: A hazai Mura-ártér fehérnyár-ligetei (Senecioni sarracenici-Populetum albae Kevey in Borhidi et Kevey 1996). Kaposvári Rippl-Rónai Múzeum Közleményei 3: 29-56.

Kevey B., BARna Cs. 2014: A hazai Felső-Tisza-vidék fehérnyár-ligetei (Senecioni sarracenici-Populetum albae Kevey in Borhidi et Kevey 1996). Botanikai Közlemények 101(1-2): 105-143.

KeVEy B., Hirmann A. 2002: „NS” számítógépes cönológiai programcsomag. In: Aktuális flóraés vegetációkutatások a Kárpát-medencében V. Pécs, 2002. március 8-10. (Összefoglalók), p. 74.

Kevey B., Huszár Zs. 1999: A Háros-sziget fehérnyár-ligetei (Senecioni sarracenici-Populetum albae Kevey in Borhidi et Kevey 1996). Természetvédelmi Közlemények 8: 37-48. 
Kevey B., Tóth V. 2006: A Baranyai-Dráva-sík fehérnyár-ligetei (Senecioni sarracenici-Populetum albae Kevey in Borhidi et Kevey 1996). Natura Somogyiensis 9: 47-62.

KIRÁLY G. (szerk.) 2009: Új magyar füvészkönyv. Magyarország hajtásos növényei. Határozókulcsok. Aggteleki Nemzeti Park Igazgatóság, Jósvafo, 616 pp.

Moor, M. 1958: Die Pflanzengesellschaften schweizerischer Flußauen. Mitteilungen der Schweizerischen Anstalt für das Forstliche Versuchswesen 34: 221-360.

Mucina L., Grabherr G., Wallnöfer S. 1993: Die Pflanzengesellschaften Österreichs III. Wälder und Gebüsche. Gustav Fischer, Jena-Stuttgart-New York, 353 pp.

MÜLLER TH., GöRS, S. 1958: Zur Kenntnis einiger Auenwaldgesellschaften im württembergischen Oberland. Beiträge zur naturkundlichen Forschung in Südwestdeutschland 17: 88-165.

Oberdorfer E. 1992: Süddeutsche Pflanzengesellschaften IV. A. Textband. Gustav Fischer Verlag, Jena-Stuttgart-New York, 282 pp.

PodAni J. 2001: Syn-Tax 2000 Computer programs for data analysis in ecology and systematics. Scientia, Budapest, 53 pp.

Soó R. 1958: Die Wälder des Alföld. Acta Botanica Academiae Scientiarum Hungaricae 4: 351-381.

Soó R. 1964, 1966, 1968, 1970, 1973, 1980: A magyar flóra és vegetáció rendszertani-növényföldrajzi kézikönyve I-VI. Akadémiai Kiadó, Budapest.

Simon T. 1957: Die Wälder des nördlichen Alföld. In: Zólyomi B. (szerk.) Die Vegetation ungarischer Landschaften 1. Akadémiai Kiadó, Budapest, 172 pp. +22 tab. +2 chart.

Szirmai O., Tuba Z., Nagy J., Cserhalmi D., Czóbel Sz., Gál B., Szerdahelyi T., MarSCHALL Z. 2008: A Bodrogköz növénytársulásainak áttekintése. In: TuBA Z. (szerk.) Bodrogköz. A magyarországi Bodrogköz tájmonográfiája. Lorántffy Zsuzsanna Szellemében Alapítvány, Gödöllő-Sárospatak, pp. 523-584.

Tóтн I. 1958: Az Alsó-Dunaártér erdőgazdálkodása, a termőhely- és az erdőtípusok összefüggése. Erdészeti Kutatások 1958(1-2): 77-160.

Elektronikus melléklet: E1-E5. táblázatok Electronic supplement: Tables E1-E5.

E1. táblázat. A Mohácsi-szigeten felvett Senecioni sarracenici-Populetum albae cönológiai felvételek összesített táblázata.

Table E1. Synoptic table of the Senecioni sarracenici-Populetum albae relevés recorded on the Mohácsi-sziget.

E2. táblázat. A Mohácsi-szigeten felvett Senecioni sarracenici-Populetum albae cönológiai felvételek adatai.

Table E2. Relevés' data for the Senecioni sarracenici-Populetum albae samples recorded on the Mohácsi-sziget.

E3. táblázat. Karakterfajok aránya fehérnyár-ligetekben (Senecioni sarracenici-Populetum albae).

Table E3. Proportion of characteristis species in white poplar riparian forests (Senecioni sarracenici-Populetum albae). 
E4. táblázat. Karakterfajok aránya a Mohácsi-sziget fehérnyár-ligeteiben (Senecioni sarracenici-Populetum albae) és tölgy-kőris-szil ligeteiben (Scillo vindobonensis-Ulmetum).

Table E4. Proportion of characteristis species in the white poplar (Senecioni sarracenici-Populetum albae) and oak-ash-elm forests in the Mohácsi-sziget (Scillo vindobonensis-Ulmetum).

E5. táblázat. Szociális magatartási típusok (SBT) aránya fehérnyár-ligetekben (Senecioni sarracenici-Populetum albae).

Table E5. Proportin of social behaviour types (SBT) in white poplar riparian forests (Senecioni sarracenici-Populetum albae).

\title{
White poplar riparian forests on the Mohácsi-sziget, South Hungary (Senecioni sarracenici-Populetum albae Kevey in Borhidi et Kevey 1996)
}

\author{
B. KEVEY \\ University of Pécs, Department of Ecology, \\ Ifjúság u. 6., H-7624 Pécs; keveyb@gamma.ttk.pte.hu
}

Accepted: 11 March 2017

Key words: Great Hungarian Plain, multivariate analysis, national park, riparian forest syntaxonomy.

In this paper the white poplar riparian forests (Senecioni sarracenici-Populetum albae) on the Mohácsi-sziget are described and characterized based on 25 phytosociological relevés. These communities grow on loose fluvial sand and raw alluvial soils on the elevated parts of the lower river floodplain. They can readily be distinguished from willow gallery forests (Leucojo aestivi-Salicetum albae) that have no shrub layer and grow in habitats $1-1.5 \mathrm{~m}$ below the level of poplar forests on rather heavy and muddy soils. They differ also from the oak-ash-elm forests (Scillo vindobonensis-Ulmetum) growing in the upper floodplain. Certain - partly sub-montane - plants that are rare or completely absent in the Great Hungarian Plain may also occur in them, such as Anemone ranunculoides, Carex brizoides, Carex remota, Carex strigosa, Carpesium abrotanoides, Fritillaria meleagris, Galanthus nivalis, Leucojum aestivum, Scilla vindobonensis, Veronica montana, Vitis sylvestris. This association is classified in the sub-alliance Populenion nigro-albae Kevey 2008 in the syntaxonomic system. 